\title{
China and the United States: Towards a New Model of Major Power Relations?
}

\author{
HU Weixing \\ Professor, Department of Politics \& Public Administration \\ University of Hong Kong
}

East Asian Policy, volume 7, issue 4 (October/December 2015), pp.14-23, http://www.eai.nus.edu.sg/publications/files/EAP_V7N4.pdf

[Abstract]

The China-US disagreement over the term of "new model of major power relations" is not just about discourse, rather, it is about who will have the upper hand in defining the terms for future China-US relations. While the Chinese want to provide a new vision and an alternative to the realist discourse of future China-US relations, the Americans believe that Beijing tries to claim a position on par with the US in world affairs.

A "new model of major power relations" (Xinxing Daguo Guanxi) between China and the United States was first proposed by then Vice President Xi Jinping in February 2012. For the Chinese, this term conveys a new vision for future China-US relations and an alternative to the realist discourse of power struggle between a rising power and a ruling power. Yet, three years have passed and this new model terminology has become a contested issue between Beijing and Washington.

Washington was initially receptive to the Chinese proposal but later became lukewarm and even suspicious of Beijing's intention. When the Chinese and American leaders met at Sunnylands in June 2013, President Obama said that, despite areas of tension in the USChina relationship, he very much looked forward to a strong foundation for the kind of "new model of cooperation" with China. ${ }^{1}$ Yet this initial positive tone soon quietly disappeared from the American official documents. In the Beijing Summit in November 2014 and, again, in the Washington Summit in September 2015, Washington avoided using this term to characterise US relations with China, despite the Chinese claim that "the two leaders agreed to continue the endeavour to build a new model of major country relationship between China and the United States based on mutual respect and win-win cooperation". 2 The US side chose to issue its own "Fact Sheet" to summarise the outcomes of the Obama-Xi summit instead of issuing a joint statement with Beijing.

${ }^{1}$ The White House, "Remarks by President Obama and President Xi Jinping of the People's Republic of China Before Bilateral Meeting", 7 June 2013, http://www.whitehouse.gov/the-pressoffice/2013/06/07/remarks-president-obamaandpresident-xi-jinping-peoples-republic-china-, accessed 10 October 2015

2 Xinhua News, "Outcome List of President Xi Jinping's State Visit to the United States," 26 September 2015, http://news.xinhuanet.com/english/2015-09/26/c_134661037.htm accessed 12 October 2015. 
The disagreement over the "new model of major power relations" between Beijing and Washington raises questions about the nature of the present China-US relations and what is an appropriate narrative of this relationship. If the two countries share common interest in avoiding conflict and better managing their competition, why a consensus on a common narrative for the relationship could not be reached? What causes the hesitation on Washington's part? Washington's reluctance to use this term means that it does not want to give the impression that the United States is in concurrence with a Chinese discourse on future China-US relations. Yet, is this just a problem of discourse or something more profound in the development of future China-US relations?

This paper examines US-China disagreement over the narrative of their relationship and what is behind the contestation over the new model of major power relations between China and the United States. It argues that the contestation over the terminology is not just about discourse, rather, it is about who will have the upper hand in defining the terms for future China-US relations. To the Chinese, the new model is a good and appropriate narrative for the future relationship. To the Americans, however, it is Chinese wishful thinking to hope to obtain unilateral concessions from Washington and to claim a position on par with the United States in world affairs. Although Beijing leaders understand that the future relationship is a wide open question, they still want to find ways to stabilise the relationship, reassure Washington and other Asian neighbours, and carefully manage its competition with Washington. In that sense, sticking to the proposal of building a new model of major power relations with the United States has great strategic value for Beijing in steering future China-US relations in years to come.

\section{Contending Discourses: the Thucydides Trap versus the New Model of Major Power Relations}

The prevalent discourse on the rise of China in the United States is a realist-based argument that rising powers are destined to challenge ruling powers and the existing international order. China is a rising power and the United States is a ruling power. It is natural and inevitable that China will challenge American dominance in the existing world order. As historical analogy shows, when a rising power challenges a ruling power, there are strong structural incentives for the rising power to displace the ruling power by war or by any other non-peaceful means. This powerful realist logic worked 2,000 years ago in the famous Peloponnesian War between Athens and Sparta and will continue to work in the future when a rising power challenges the ruling power. This logic has been termed the "Thucydides Trap" by international relations scholars.

The "Thucydides Trap" and historical analogy not only are popular, but also have a powerful framing effect on the Western elites' thinking about the China challenge. From John Mearsheimer's The Tragedy of Great Power Politics and "China's Unpeaceful Rise" to Aaron Friedberg's A Contest for Supremacy and Ted Carpenter's America's Coming War with China, the realist logic speaks loudly in the debate over the rise of China and future US-China relations. ${ }^{3}$ It has provided a ready narrative framework to deriving at the implications of a rising China for the future China-US relationship.

\footnotetext{
${ }^{3}$ John J Mearsheimer, The Tragedy of Great Power Politics, New York, W W Norton, 2001 and "China's Unpeaceful Rise", Current History, vol. 105, no. 690, April 2006, pp. 160-162; Aaron L. Friedberg, A Contest for Supremacy: China, America, and the Struggle 
A recent research project led by Harvard Professor Graham Allison has further popularised the narrative of the Thucydides Trap on China-US relations. The Harvard University's Thucydides Trap project is an applied history project. Its purpose is to examine historical precedents and analogs that could illuminate how a ruling power challenges a rising power and whether it would lead to war. The Harvard project has compiled 16 cases so far and 12 out of 16 cases of a rising power's rivalry with a ruling power since 1500 led to war, and only four cases did not end in bloodshed. As Allison argues, "[The] defining question about global order for this generation is whether China and the United States can escape the Thucydides Trap ....... When the parties avoided war, it required huge, painful adjustments in attitudes and actions on the part not just of the challenger but also the challenged." 4

To argue against the prevailing Western narrative (including the Thucydides Trap), Beijing intends to create an alternative discourse to the realist narrative on future China-US relations. The positive side is that the present China-US relationship is one of neither friends nor foes and neither country wants to go to war with one another. Unlike US-Soviet relations in the Cold War, China and the United States do not want to sour the relationship. Chinese leaders have expressed that China has neither the interest nor intention to challenge the postwar international system and the primary US position in the world order. Despite Beijing's constant reassurance to the world of its peaceful rising intention, the realist logic in international relations is so overwhelming that few would believe China's rise will not eventually challenge the dominant position of the United States in world affairs. The Chinese thus have to create new discourse to argue against the narrative of the Thucydides Trap within the international community.

During his recent state visit to the United States, President Xi Jinping told his audience in Seattle that "[There] is no such thing as the so-called Thucydides Trap in the world. But should major countries time and again make the mistakes of strategic miscalculation, they might create such traps for themselves". The argument targets the self-fulfilling prophecy of the Thucydides Trap and attempts to convince the American audience that the Thucydides Trap is not inevitable so long as the leaders of major powers do not create such traps for themselves.

For the Chinese, another purpose of the new model of major power relations is to suggest the need to find ways to peacefully coexist and develop together as the two countries have tremendous differences over their political institutions, cultural traditions and economic systems. As former Australian Prime Minister Kevin Rudd argues, there has been no common narrative of any description to frame major power relations in the post-Cold War era. It is thus imperative for Beijing and Washington to construct such a framework. The framework would enable the two countries to accommodate fundamental disagreements

for Mastery in Asia, New York, W W Norton, 2011; and Ted G Carpenter, America's Coming War with China: A Collision Course Over Taiwan, New York, St. Martin's 2005.

${ }^{4}$ Graham T Allison, "The Thucydides Trap: Are the U.S. and China Headed for War?" The Atlantic, 24 September 2015, http://www.theatlantic.com/international/archive/2015/09/united-states-china-warthucydides-trap/406756/ accessed 12 October 2015. 
and cooperate over substantive regional and global issues at the same time. This is what he calls constructive realism. ${ }^{5}$

For the American audience as well as US policy elites, they may not be convinced by the Chinese narrative. However it is also in America's interest to avoid the Thucydides Trap. For this reason, Washington has stated that it does not seek to contain the rise of China but welcomes the rise of a peaceful and prosperous China. American leaders hope that engagement with China would help integrate the rising power into the existing international order and gradually transform its political system and international behaviour.

\section{Obama's Pivot to Asia and Changes in US China Policy}

Moving beyond the contending discourses, the Chinese proposal for a new model of major power relations with the United States has its practical purpose. It was unveiled at a time when tensions in China-US relations began to rise as the Obama administration started its "pivot to Asia" strategy in 2011-2012. China-US relations were largely stable for the first two years of the Obama presidency. Tensions began to build up when the Obama administration perceived that Beijing became more assertive in foreign policy and decided to rebalance its strategic attention and resources towards the Asia Pacific region. In some sense, the new model proposal was Beijing's response to the Obama administration's "pivot to Asia" strategy.

The US China policy has oscillated between engagement and containment in the post-Cold War era. While the United States wants to engage China, it keeps a dominant military posture in the Asia-Pacific to hedge against China's rise. From Clinton to Bush, this "engagement plus hedging" policy played out well. In 2005, Deputy Secretary of State Robert Zoellick encouraged China to become a "responsible stakeholder" in the international system. In 2009 when Obama first came to office, his administration had high expectations of further elevating US-China cooperation to cope with the global financial crisis and other thorny regional issues. However, the "engagement plus hedging" policy was reversed in 2011 when Chinese economic and military power grew fast and, in the American perception, Beijing has become more assertive in its international behaviour.

The idea of a "Pivot to Asia" was first introduced by then Secretary of State Hillary Clinton. In an article titled, "America's Pacific Century" published in Foreign Policy magazine in October 2011, she argues: "Over the last 10 years, we have allocated immense resources to those two theaters [Iraq and Afghanistan]. In the next 10 years, we need to be smart and systematic about where we invest time and energy, so that we put ourselves in the best position to sustain our leadership, secure our interests, and advance our values. One of the most important tasks of American statecraft over the next decade will therefore be to lock in a substantially increased investment - diplomatic, economic, strategic, and otherwise -in the Asia-Pacific region". 6 The global "War on Terror" during the George W Bush administration had led to the United States' preoccupation with the Middle East. When Obama came to office, most American elites and policymakers agreed that America's wars

\footnotetext{
${ }^{5}$ Kevin Rudd's interview with Caixin magazine, 15 May 2015, http://english.caixin.com/2015-05-15/100809611.html accessed 4 October 2015.

${ }^{6}$ Hillary Clinton, “America's Pacific Century”, Foreign Policy, 11 October 2011, $<$ http://www.foreignpolicy.com/articles/2011/10/11/americas_pacific_century $\geq$ accessed 15 August 2014.
} 
in Iraq and Afghanistan had seriously undermined its ability to respond to major power shifts in the Asia-Pacific region and that there was a need for Washington to reorientate its foreign policy focus to Asia.

Although Washington has claimed that the rebalancing does not mean containing China, US strategic rebalancing, since being unveiled, has been widely interpreted, or at least perceived, by the Chinese as a major step to balance or contain the rise of China in East Asia. This perception is strong and powerful, and has generated a great deal of debate about future major power relations in the region. For Washington, the rise of China is a central concern in its global strategic rebalancing, but it is not the only consideration as the rebalancing is a multidimensional strategy, not entirely about China. In the eyes of Chinese elites, however, any declared disinterest in containing China is simply empty rhetoric. Most Chinese elites believe the purpose of the "Pivot to Asia" is to contain China, or at least undermine China's growing regional influence. Although a small number of Chinese analysts do not accept the conspiracy argument, they still believe that American rebalancing will inevitably lead to the weakening of China's strategic position and influence in East Asia. President Obama's tour of four East Asian countries surrounding China in April 2014 and the new US-Philippines defence agreement gave further credence to the Chinese fear that Washington aims to form a regional coalition against China in East Asia.

Regardless of the assessments, most Chinese analysts seem to agree that Obama's rebalancing to Asia will test China's regional policies and its future in East Asia in three areas: (1) the enhanced US military presence in the region; (2) the Trans-Pacific Partnership (TPP) initiative and its implications for future regional institution building; and (3) the future US role in regional territorial and maritime disputes.

\section{The Chinese Response to Washington's "Pivot to Asia"}

US rebalancing to Asia has created new regional dynamics and shaping effect on major power relations in the Asia-Pacific region. There is no doubt that the rebalance to Asia is a game changer for China and its relations with the United States. China's threat perception has undergone significant revision due to US rebalancing to Asia. US rebalancing aims to strengthen the American alliance system and relations with emerging powers in the region, which have significant impact on power relations throughout the region.

Since becoming the president, Xi Jinping attempted to re-set or stabilise relations with Washington. In response to US rebalancing, Beijing seeks to avoid direct conflict, increase mutual respect and create win-win cooperation with Washington while rebalance China's overall foreign strategy westward and diplomatically reaching out to Russia, Africa and Latin America. As it firmly safeguards its national interests and maritime rights, Beijing is also actively cultivating economic relations of mutual benefit with countries in Eurasia and Southeast Asia, and promoting the development of the Silk Road Economic Belt and the 21st Century Maritime Silk Road (One Belt One Road) to further bolster its relations with these countries.

Thus far, China's response to the rebalancing has been non-confrontational, but also uncompromising in terms of defending its national interests in the region. Beijing understands that it is a weaker, but rising, power vis-à-vis the existing dominant power in the Asia-Pacific region. China is not strong enough for a "showdown" with the United 
States over its rebalance to the region and efforts to restrain China's rising influence. Beijing has sought to answer the rebalancing challenge in a Chinese way, rather than engaging in direct confrontation with Washington. China's response attempts to maintain its interest and influence in the region while avoiding war and conflict with the United States. The Chinese response seeks to walk the realist tightrope of both competing with and cooperating with Washington. It is a Chinese way to play the weaker party "game" and contest with a stronger power.

The initial Chinese proposal of the new model of major power relations included three pillars: (1) avoidance of conflict or confrontation between the two countries, (2) mutual respect on important matters of concern and (3) pursuit of cooperation by renouncing a zero-sum-game mindset. It was later watered down to a relationship based on "mutual respect" and "win-win cooperation". For China, it believes that a non-confrontational relationship with the United States is essential for China's international environment as it enables China to focus on economic development. Based on this mutual understanding, both China and the United States could build a stable, cooperative and constructive relationship in which they can expand cooperation over issues of converged interests while managing competition in the areas where interests diverge.

The American concern of the new model discourse is understandable. To Americans, Beijing tries to use the concept or the "slogan" to secure unilateral concessions from Washington on issues concerning Chinese "core national interests". Some American analysts argue that the new model "appears to require Washington to accommodate China's interests and to do so largely on Beijing's terms - apparently without reciprocal adjustments". 7 The difference in cultural backgrounds explains the huge expectation gap between Beijing and Washington on the new model discourse. For Washington, it is more interested in concrete steps of actions, not just rhetoric. Washington has shown growing concern about China's rapid pace of military modenisation, unfair trade practices and more assertive actions in the East and South China Seas, such as the declaration of the ADIZ. It has demanded for Chinese concrete actions on policy issues, rather than agreeing to a visionary statement.

\section{Major Obstacles to the New Model of Major Power Relations}

The difference between Beijing and Washington also reflects more profound problems in building a stable China-US relationship. One of the biggest obstacles to the stable relationship is the lack of mutual strategic trust. Trust is gained through continuous reciprocal exchanges, so that one learns over time that the other side will not exploit one's goodwill and will return cooperation with cooperation. This process, and with the development of trust over time, requires that the prospective rewards of future interactions are greater than any momentary gain to be made from opportunistic behaviour. Over the last decade, China and the United States have developed a series of dialogues at different levels, including the Strategic and Economic Dialogues. However, in these dialogues, each side has focused more on what the other side should do, rather than on what China and the United States both must do.

\footnotetext{
${ }^{7}$ Michael Chase, "China's Search for a 'New Type of Great Power Relationship"', China Brief, vol. 12, no. 17, 2012, pp. 12-16.
} 
The more profound basis for building a new model of major power relations between China and the United States thus concerns the extent of the trust and willingness to accept the other's role in world affairs. As former National Security Advisor Stephen Hadley put it, "Is the United States ready to accept an increasingly powerful China playing an enhanced role on the world stage - perhaps ultimately a role on a par with that played by the United States itself? Is the United States ready to accept that as China's economy grows, it will build a larger, more capable ocean-going naval force to protect the sea lanes from which China receives the energy, resources, and global trade on which it increasingly depends? Is the United States willing to counsel restraint to its friends and allies in the Asia-Pacific region and urge them to make efforts to find a compromise with China on issues where China feels strongly that its interests are threatened?",

Most Chinese elites believe that the United States could accept China's future leading position in such areas as gross domestic product, volume of foreign trade and diplomatic/economic impact in Asia, and to a less degree, the mutual strategic deterrence between the two countries, along with the peaceful co-existence of the two great powers. Washington however would never accept a future Chinese military advantage over the United States. China's relatively marginal military advantage against the United States in the West Pacific could provide it with sizeable "strategic space" in East Asia - meaning the off-shore waters along the South China Sea, the Taiwan Strait and up to the Korean Peninsula (beyond what is the first island chain). The dominant role of the United States in East Asia has been built on Washington's overall military superiority in the West Pacific, east of Okinawa and Guam, under the San Francisco System after 1945, which consolidated its position in Asia.

China's future role in East Asia and the balance of power between China and the United States are contingent on their respective strengths and contributions to regional governance in the Asia-Pacific region. There is a tendency towards bifurcation in Asian Pacific international relations: regional countries turn to China seeking economic benefits and to the United States seeking security. This situation creates possibilities of power-sharing, consultation and selective collaboration between Beijing and Washington. In economic and financial affairs, the United States needs China to play a more constructive role in East Asia. Although China-US relations have been frequently affected by problems in regional and third-country affairs, situational friction and competition, it is not impossible to have a more positive and cooperative China-US relationship. In such a scenario, the United States would need to accept a peaceful and constructive China as a rising world power, and China, in turn, should respect the essential interests and rightful international concerns of the United States as a dominant world power.

\section{Differences and Shared Interests}

China-US relations are complex. The two countries have huge differences over political system, culture and values, but also huge common and shared interests over global challenges. The United States and China have exceedingly interdependent economic ties and inter-societal exchanges. Neither side can afford head-on confrontation. They must

\footnotetext{
${ }^{8}$ Stephen J. Hadley’s speech, “Asia-Pacific Major Power Relations and Regional Security,” World Peace Forum, Beijing, 21 June 2014, $<$ http://www.wpfforum.org/index.php? $\mathrm{m}=$ content $\& \mathrm{c}=$ index \&a=show \&catid=95\&id=266 $\geq$ accessed 15 December 2014.
} 
carefully manage this "neither enemy nor friend" relationship. Although China-US relations have frequently been affected by problems in regional and third-country affairs, situational frictions and competition, it is not impossible to have a more positive and cooperative China-US relationship. In such a scenario, the United States accepts a peaceful and constructive China as a world power, and China, in turn, will respect the essential interests and rightful international concerns of the United States as a world dominant power.

If the Obama administration's strategic rebalancing is a response to the rapid rise of China in Asia, Beijing's response to the "pivot" is shaped by China's perception of the "deteriorating" international environment in the Asia-Pacific. This action-reaction pattern of major power strategic interaction would eventually lead them to the "security dilemma" and the Thucydides Trap. Leaders of major powers would need to avoid miscalculation and misjudgment about each other's strategic intentions. Effective strategic communication and dialogues are required for China and the United States to reassure one another's strategic intentions, as mutual trust is the basis for stable major power relations and international stability.

In response to US rebalancing to Asia, the Chinese leadership has so far avoided taking a sharply confrontational stance. The strategic rebalancing could be a source of conflict with China, but it also provides an opportunity to engage and gradually integrate China into the existing regional international system. The interaction process would be prolonged and challenging. It requires both China and the United States to follow a balanced and pragmatic policy when dealing with each other. Central to future regional security and stability in East Asia is whether Beijing and Washington can find ways to effectively manage their competition while expanding cooperation and developing a genuinely new model of major power relations. 